\title{
Research on Mg-Zn-Ca Alloy as Degradable Biomaterial
}

\author{
B.P. Zhang1,2, Y. Wang 2 and L. Geng'2 \\ ${ }^{1}$ National Engineering Laboratory for Carbon Fiber Technology, \\ Institute of Coal Chemistry, Chinese Academy of Sciences \\ ${ }^{2}$ School of Materials Science and Engineering, Harbin Institute of Technology \\ China
}

\section{Introduction}

Magnesium and magnesium alloys are light metals, which characterized a low density, high specific strength and strong specific stiffness. The fracture toughness of magnesium is greater than that of ceramic biomaterials such as hydroxyapatite. The Young's elastic modulus and compressive yield strength of magnesium are closer to those of cortical bone. Especially, $\mathrm{Mg}^{2+}$ is present in large amount in the human body and involved in many metabolic reactions and biological mechanisms. The human body usually contains approximately $35 \mathrm{~g}$ per $70 \mathrm{~kg}$ body weight and the human body's daily demand for $\mathrm{Mg}$ is about $350 \mathrm{mg} /$ day. Due to the excellent biomechanical properties and biocompatibility, magnesium alloys used to be introduced as implants into orthopedic and trauma surgery in recently years [1 3].Various magnesium alloys have been investigated as biodegradable materials and some of them have been shown good biocompatibility. For example, AZ31, AZ91, WE43, LAE442, Mg-Ca and Mg-Zn have been investigated for bone implant application [4 8]. It has been shown that magnesium enhances osteogenesis response and increases newly formed bone. However, some magnesium alloys containing aluminum or heavy metal elements which have latent toxic effects on the human body. Thus, several problems such as inadequate strength, rapid corrosion and toxic ions must be solved before this unique metal is widely used in biomedical fields.

It is well known that pure magnesium has poor mechanical properties and the mechanical properties of magnesium can be effectively improved by the appropriate selection of alloying elements [1]. But, based on the aforementioned considerations, the range of alloying elements used in the degradable magnesium alloys is rather limited, $\mathrm{Zn}, \mathrm{Mn}, \mathrm{Ca}$ and perhaps a very small amount of low toxicity RE can be tolerated in the human body and can also be retard the biodegradation. Therefore, $\mathrm{Mg}$-Ca binary alloys attract attention of researchers because $\mathrm{Ca}$ is an important element of human bones. The mechanical properties and biocompatibility of Mg-Ca binary alloy can be adjusted by controlling the Ca content and processing treatment. However, an inadequate mechanical properties as well as lower corrosion resistances of Mg-Ca binary alloys are the biggest drawback of these alloys [7][8]. Fortunately, in latest recent years, $\mathrm{Mg}-\mathrm{Zn}$ system is paid more attention because $\mathrm{Zn}$ is one of abundant nutritional elements in human body [9] [10]. Additionally, it is a great potential 
alloying element to improve the mechanical properties and corrosion resistance of $\mathrm{Mg}$ alloys [11][12]. And the addition of other alloying element can further improve the mechanical properties of $\mathrm{Mg}-\mathrm{Zn}$ alloys [13] [14]. Zn/Mn-containing magnesium alloys, e.g. Mg2Zn0.2Mn [15] and Mg-1.2 Mn-1.0 Zn [16] ternary alloys are studied, the results indicate that $\mathrm{Zn} / \mathrm{Mn}$-containing magnesium alloys have satisfactory mechanical properties and can be potential biodegradable alloys. But, the degradation rates of $\mathrm{Zn} / \mathrm{Mn}$-containing magnesium alloys are so fast. After 9 weeks implantation, about 10 17\% Mg-Mn-Zn magnesium implant has degraded. After 18 weeks implantation, about 54\% Mg-Mn-Zn alloy has degraded [16]. The results studied by H.X. Wang at al [17] indicate that the Mg-ZnCa alloys coated with Ca-deficient hydroxyapatite have an excellent corrosion resistance in Kokubo's simulated body fluid (SBF), but the chemical composition of $\mathrm{Mg}-\mathrm{Zn}$-Ca alloys was not reported. L.Mao et al [18] studied the effects of Zn on microstructure and mechanical properties of biomedical Mg-Ca-Zn alloys. The results show that the microstructure is refined and the mechanical properties can be improved evidently with $\mathrm{Zn}$ content increasing. The mechanical properties of bending and compression can meet the requirements for hard tissue metal implants. However, the effect of $\mathrm{Ca}$ on microstructure and mechanical properties of biomedical Mg-Ca-Zn alloys, the corrosion resistance and cytotoxicity were not studied. Xuenan Gu et al[19] reported that the Mg66Zn30Ca4 bulk metallic glasses sample presents a more uniform corrosion morphology than as-rolled pure $\mathrm{Mg}$ and Mg70Zn25Ca5 samples. Both indirect cytotoxicity and direct cell culture experiments were carried out using L929 and MG63 cell lines. The results show higher cell viabilities for $\mathrm{Mg}-\mathrm{Zn}$-Ca extracts than that for as-rolled pure $\mathrm{Mg}$. In addition, $\mathrm{L} 929$ and MG63 cells were found to adhere and proliferate on the surface of Mg66Zn30Ca4 sample. Unfortunately, the cytotoxicity was tests by MTT, according Janine Fischer et.al[20] research, in the case of Mg materials, the use of MTT test kits leads to false positive or false negative results, because $\mathrm{Mg}$ is a very reactive element. It is conceivable that $\mathrm{Mg}$ in the highly alkaline environment may be able to open the ring form of the tetrazolium salt and bind to it, which could lead to a change in colors similar to the formation of formazan in the case of the MTT tests with cells.

It is reasonable to speculate that the $\mathrm{Mg}$ - $\mathrm{Zn}$-Ca alloys with a proper $\mathrm{Zn}$ and Ca content can exhibit a superior combination of mechanical properties, corrosion resistance and biocompatibility. In this paper, $\mathrm{Zn}$ and $\mathrm{Ca}$, which have no toxicity, are chosen as alloying elements to successfully improve the mechanical properties of magnesium. The effects of $\mathrm{Zn}$ and Ca content on mechanical properties, in-vitro corrodible property and cytotoxicity of $\mathrm{Mg}-\mathrm{Zn}$-Ca alloys have been systematic investigated to assess the feasibility of $\mathrm{Mg}$ - Zn-Ca alloys for use as bone implant materials.

\section{Materials and methods}

\subsection{Materials}

Mg-Zn-Ca alloys were prepared from high purity Mg (99.99 \%), Purity Zn (99.8 \%), and an Mg-26.9 wt. \% Ca master alloy. Melting and alloying operations were carried out in a steel crucible under the protection of a mixed gas atmosphere of $\mathrm{SF}_{6}(0.3 \mathrm{vol} . \%)$ and $\mathrm{CO}_{2}(\mathrm{Bal}$.). Purity $\mathrm{Zn}$ and master alloy were added into the pure $\mathrm{Mg}$ melts at $720{ }^{\circ} \mathrm{C}$. The melts were kept for $10 \mathrm{~min}$ at $720^{\circ} \mathrm{C}$ to ensure that all the required alloying elements were dissolved in the melt alloy, and then the melts were cooled down to $700{ }^{\circ} \mathrm{C}$ and poured into a steel mold which had been pre-heated to $200{ }^{\circ} \mathrm{C}$. 


\subsection{Composition and microstructure characterization}

X-ray diffraction (XRD, Philips-X'Pert) using $\mathrm{Cu} \mathrm{Ka}$ radiation was employed for the identification of the constituent phases in the as-cast $\mathrm{Mg}-\mathrm{Zn}-\mathrm{Ca}$ alloy and their corrosion products after immersion. Microstructure observations of the alloys were conducted on Olympus optical microscope. The specimens for optical microscopy were etched with a solution of 8 vol. \% acetic acid for $30 \mathrm{~s}$, thoroughly flushed with water and alcohol, and then dried by hot air.

\subsection{Mechanical properties}

Tensile tests were carried out using an Instron-5569 universal testing machine at a constant crosshead speed of $1.0 \mathrm{~mm} / \mathrm{min}$ at room temperature. The tensile specimens with diameter of $6 \mathrm{~mm}$ and gauge length of $30 \mathrm{~mm}$ were cut by electric-discharge machining from the ingot. The Young's modulus was get from the tensile test. The fracture morphologies were examined by SEM (SEM, Hitachi-3000N).

\subsection{In vitro degradation tests}

Electro-chemical measurements and immersion tests were performed in a Hank's simulated body fluid to evaluate the in-vitro degradation properties. The chemical composite of Hank's simulated body was listed in table 2.The $\mathrm{pH}$ value of Hank's solution was adjusted with $\mathrm{HCl}$ and $\mathrm{NaOH}$ to 7.2 7.4, to avoid precipitation or formation of sediments in the solution. Its temperature was controlled around $37 \pm 0.5{ }^{\circ} \mathrm{C}$, which is equal to the human body normal temperature. Pure Mg (>99.99\%) was also tested as a contrast.

\subsubsection{Electrochemical measurements}

A typical three-electrode system consisting of graphite rod as counter electrode, saturated calomel electrode (SCE) as a reference electrode and specimen $\left(1 \mathrm{~cm}^{2}\right.$ exposed areas) as a working electrode was used. Potentiodynamic polarization experiments were carried out at a scan rate of $0.5 \mathrm{mV} / \mathrm{s}$. The electrochemical measurements of specimens with thickness of 4 $\mathrm{mm}$ and a gauge diameter of $15 \mathrm{~mm}$ were machined from the ingot and ground with 2000 grit $\mathrm{SiC}$ paper, and they were rinsed with distilled water and dried by hot air.

\subsubsection{Immersion tests}

The immersion tests were carried out in Hank's solution according to ASTM-G31-72 [21]. Samples were removed after 30 days of immersion, rinsed with distilled water, and were cleaned with chromic acid to remove the corrosion products. The degradation rates (in units of mm year-) were obtained according to ASTM-G31-72. An average of five measurements was taken for each group. The $\mathrm{pH}$ value of the solution was also recorded in the immersion tests at absolute group for 144 hours.

\subsection{Cytotoxicity assessments}

L-929 cells were adopted to evaluate the cytotoxicity of $\mathrm{Mg}-\mathrm{Zn}$-Ca alloys. The cells were cultured in Dulbecco's modified Eagle's medium (DMEM), 10\% fetal bovine serum (FBS), $100 \mathrm{Uml}^{-1}$ penicillin and $100 \mathrm{mg} \mathrm{ml}^{-1}$ streptomycin at $37{ }^{\circ} \mathrm{C}$ in a humidified atmosphere of $5 \%$ $\mathrm{CO} 2$. The cytotoxicity tests were carried out by indirect contact. Extracts were prepared using DMEM serum free medium as the extraction medium with the surface area of extraction medium ratio $1.25 \mathrm{ml} / \mathrm{cm}^{2}$ in a humidified atmosphere with $5 \% \mathrm{CO}_{2}$ at 37 o $\mathrm{C}$ for 
$72 \mathrm{~h}$. The supernatant fluid was withdrawn and centrifuged to prepare the extraction medium, then refrigerated at $4 \circ \mathrm{o}$ before the cytotoxicity test. The control groups involved the use of DMEM medium as negative controls. Cells were incubated in 96-well cell culture plates at $5 \times 10^{4}$ cells $/ \mathrm{ml}$ medium in each well and incubated for $24 \mathrm{~h}$ to allow attachment. The medium was then replaced with $100 \mu \mathrm{l}$ of extracts. After incubating the cells in a humidified atmosphere with $5 \% \mathrm{CO} 2$ at $37{ }^{\circ} \mathrm{C}$ for 2, 4 and 7 days, respectively, cell morphology was observed by optical microscopy (Nikon ELWD 0.3 inverted microscope).The neutral red viability assay was performed according to published procedures. A stock solution of neutral red (Beyotime, China) was prepared in water $(1 \%)$. The stock solution was diluted to $50 \mu \mathrm{g} / \mathrm{ml}$ in complete culture medium and $200 \mu \mathrm{l}$ of the staining solution were added to each well after removal of the exposure medium. The cells were incubated for $3 \mathrm{~h}$ at $37^{\circ} \mathrm{C}$, The cells were then fixed with $200 \mu \mathrm{l}$ formaldehyde/ $\mathrm{CaCl} 2(3.7 \% / 1 \%)$ and destained with $200 \mu \mathrm{l}$ methanol/glacial acetic acid (50\%/1\%), The plates were shaken for $60 \mathrm{~min}$ at room temperature using a plate shaker. Optical densities were measured at $540 \mathrm{~nm}$ in a multiwell spectrophotometer (Bio-RAD 680). The cell relative growth rate (RGR) was calculated according to the following formula:

$$
\mathrm{RGR}=\mathrm{OD}_{\text {test }} / \mathrm{OD}_{\text {negative }} \times 100 \%
$$

\subsection{Animal test}

\subsubsection{Surgery}

Animal tests were approved by the Ethnics Committee of the First Affiliated Hospital of Harbin Medical University. The in-vivo degradation experiments were performed in the animal laboratory of the hospital. A total of 15 adult New Zealand rabbits (6 females), $2.0 \sim 2.5 \mathrm{~kg}$ in weight, were used. In the experimental group, sodium pentobarbital $(30 \mathrm{mg} \mathrm{kg}$ 1) was administered to perform anesthesia by intravenous injection. The sterile Mg-Zn-Ca alloy rod sample was implanted into the femora of the rabbit.

After operation, all animals received a subcutaneous injection of penicillin to avoid a wound contamination and were allowed to move freely in their cages without external support. After operation, five rabbits were sacrificed randomly at 1,2 and 3 months, respectively.

\subsubsection{Degradation and histological analysis}

The bone samples with magnesium implants were fixed in $2.5 \%$ glutaraldehyde solution and then embedded in epoxy resin for microstructure analysis. The samples were sliced by hard tissue slicer (ZJXL-ZY-200814-1). Samples were made perpendicular to the long axis of the implant to get a cross-section of the implant and surrounding bone tissue. The crosssection microstructure was observed by an optical microscope (Nikon ELWD 0.3 inverted microscope) and a scanning electronic microscope (Hitachi S-5500). The residual implant areas were measured on the cross-section images using analysis software. The ratio of the residual cross-section area of implants to the original cross-section area (residual area/implant area $\times 100 \%$ ) was used to assess the in vivo degradation rate of magnesium alloys. The element distributions in the residual implants and the degradation layer after 3 months implantation were analyzed.

For histological analysis, the bone samples with magnesium implants were fixed in $4 \%$ formaldehyde solution, dehydrated, and then decalcified in ethylene diamine tetra acetate. Then, the specimens were embedded in paraffin and cut into films with $5 \mu \mathrm{m}$ in thickness. 
The films were then stained with Hematoxylin and eosin. Histological images were observed on an optical microscope.

\subsection{Statistical analysis}

A t-test was used to determine whether any significant differences existed between the mean values of the cytotoxicity and animal tests of the experiment. The statistical significance was defined as $\mathrm{P}<0.05$.

\section{Results and discussion}

\subsection{Phase compositions and microstructures evolution of the as-cast $\mathrm{Mg}-\mathrm{Zn}-\mathrm{Ca}$ alloys 3.1.1 The effects of $\mathrm{Zn}$ content on phase compositions and microstructures of the as-cast alloys}

In this study, in order to investigated the effects of $\mathrm{Zn}$ and $\mathrm{Ca}$ on the phase compositions and microstructures evolution of the as-cast $\mathrm{Mg}$ - Zn-Ca alloys, respectively, the initial content of $\mathrm{Ca}$ design as $0 \mathrm{wt}$. \% and then changed the content of $\mathrm{Zn}$ to study the effects of $\mathrm{Zn}$ on phase compositions and microstructures. The chemical compositions of the $\mathrm{Mg}-\mathrm{xZn}$ alloy obtained by ICP-AES were listed in Table 1 . The impurity contents of the $\mathrm{Mg}-\mathrm{x} \mathrm{Zn}$ alloy were very low for better degradation properties and biocompatibility. X-ray diffraction (XRD) analyses were used to investigate the existing intermetallic phases in the $\mathrm{Mg}-\mathrm{x} \mathrm{Zn} \mathrm{Ca}$ alloys (Fig. 1). As shown in Fig. 1, there was only a-Mg diffraction peaks phase in the $\mathrm{Mg}-1.0 \mathrm{Zn}$ alloy. Diffraction peaks from the $\mathrm{Mg}_{2} \mathrm{Zn}$ phase was not detected. With the $\mathrm{Zn}$ concentration increasing, MgZn phase's patterns were began to detect in $\mathrm{Mg}-5.0 \mathrm{Zn}$ and $\mathrm{Mg}-6.0 \mathrm{Zn}$ alloy.

\begin{tabular}{lcccccc}
\hline \multirow{2}{*}{ Materials } & \multicolumn{6}{c}{ Chemical composition (wt.\%) } \\
\cline { 2 - 7 } & $\mathrm{Al}$ & $\mathrm{Zn}$ & $\mathrm{Mn}$ & $\mathrm{Si}$ & $\mathrm{Fe}$ & $\mathrm{Mg}$ \\
\hline Mg-1.0Zn & 0.023 & 0.976 & 0.058 & 0.031 & 0.004 & Balance \\
Mg-2.0Zn & 0.033 & 1.852 & 0.030 & 0.039 & 0.007 & Balance \\
Mg-3.0Zn & 0.029 & 2.732 & 0.022 & 0.036 & 0.007 & Balance \\
Mg-4.0Zn & 0.019 & 3.925 & 0.021 & 0.032 & 0.008 & Balance \\
Mg-5.0Zn & 0.027 & 5.223 & 0.031 & 0.034 & 0.009 & Balance \\
Mg-6.0Zn & 0.024 & 5.977 & 0.019 & 0.033 & 0.012 & Balance \\
\hline
\end{tabular}

Table 1. Chemical compositions of the as-cast Mg-Zn alloy

The microstructures of the as-cast Mg-x Zn alloys were shown in Fig.2. Fig. 2(a) was taken from $\mathrm{Mg}-1.0 \mathrm{Zn}$ alloy, in which the microstructure consists of the a-Mg. The maximum solubility of $\mathrm{Zn}$ in the magnesium was about $2 \mathrm{wt}$ \% at room temperature in the equilibrium state, when no more than $2 \mathrm{wt}$. \% Zn was added, the Zn was solid solution in $\mathrm{Mg}$ matrix. When the contents of Zn was more than $4 \mathrm{wt}$. \% , the microstructure obviously changed, there were more second phases precipitated and the morphogenesis of second phases were small particle. As shown in Fig.2 (f), with the increasing of Zn content, lamellar eutectic appears in the as-cast microstructure. The eutectic structures were very coarse and mostly distributed in the grain boundary and less in the areas of inter-dendrite, 


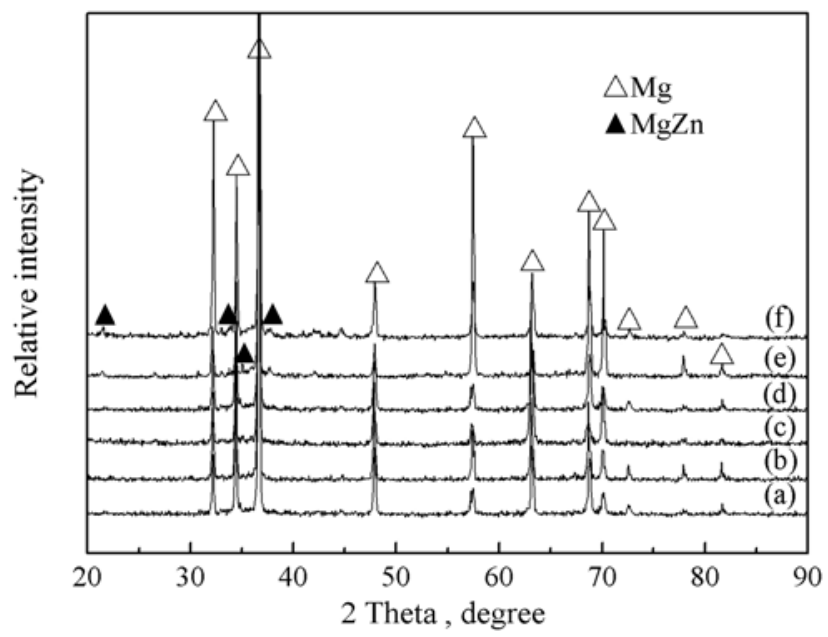

Fig. 1. XRD patterns of as-cast Mg-Zn alloys (a)Mg-1.0Zn; (b)Mg-2.0Zn; (c)Mg-3.0Zn; (d)Mg4.0Zn; (e)Mg-5.0Zn; (f)Mg-6.0Zn

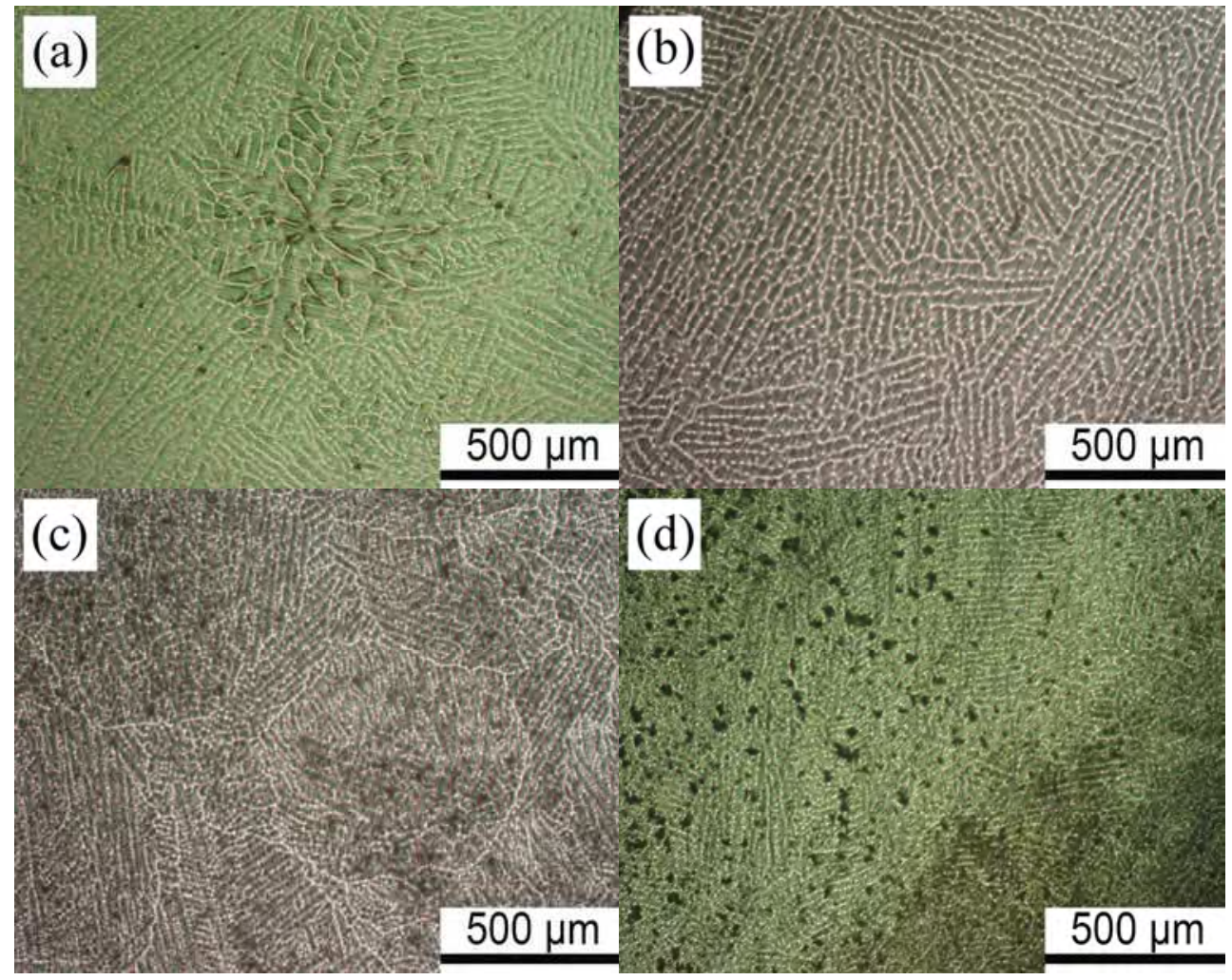




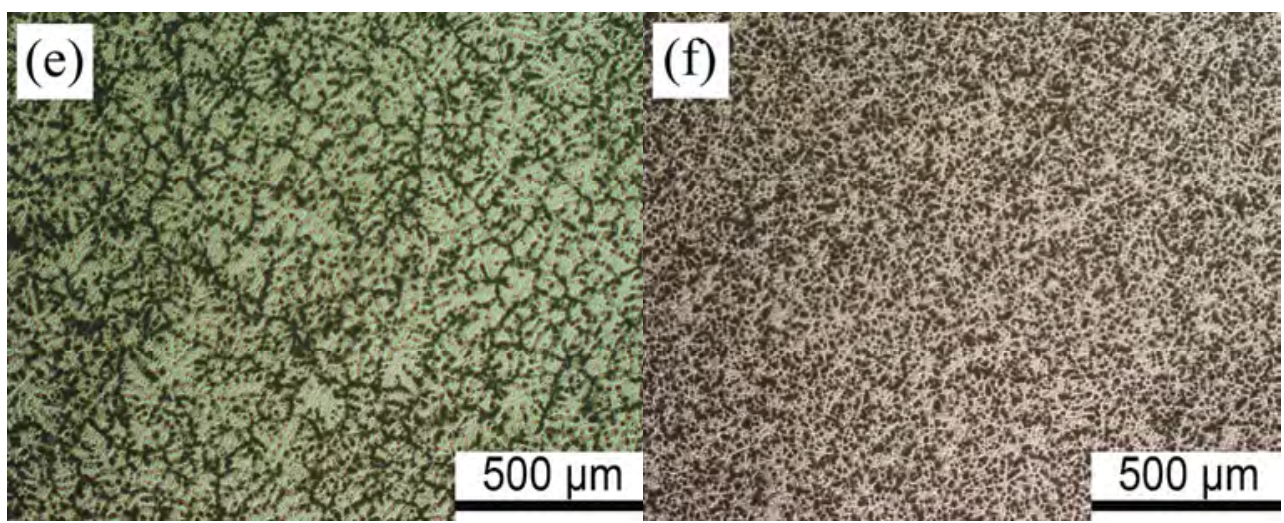

Fig. 2. Optical microstructure of as-cast Mg-Zn alloys (a) Mg-1.0Zn; (b) Mg-2.0Zn; (c) Mg3.0Zn; (d) Mg-4.0Zn; (e) Mg-5.0Zn; (f) Mg-6.0Zn

\subsubsection{The effects of Ca content on phase compositions and microstructures of the as-cast alloys}

In present study, the mechanical properties show that when $\mathrm{Zn}$ content is $4 \mathrm{wt}$. \%, the Mg$\mathrm{xZn}$ has good mechanical properties. Thus, the initial content of $\mathrm{Zn}$ designs as $4.0 \mathrm{wt}$. \% and then changed the content of $\mathrm{Ca}$ to study the effects on phase compositions and microstructures .The chemical compositions of the Mg-4.0 Zn-x Ca alloy obtained by ICPAES were listed in Table 3. X-ray diffraction (XRD) analyses were used to investigate the existing phases in the $\mathrm{Mg}-4.0 \mathrm{Zn}-\mathrm{xCa}$ alloys, and the results were shown in Fig.3. The results showed that a-Mg and MgZn phases were detected in the Mg-4.0 Zn alloy, and it also indicated that the diffraction peaks from the $\mathrm{MgZn}$ phase were very weak and that of the $\mathrm{Mg}$ were strong. There was no obvious change in diffraction peak when $0.2 \mathrm{wt}$. \% Ca and $0.5 \mathrm{wt}$. \% Ca was added into the Mg-4.0 Zn alloy. With the Ca concentration increased to 1.5 wt. \%, $\mathrm{Ca}_{2} \mathrm{Mg}_{6} \mathrm{Zn}_{3}$ phases began to be detected in $\mathrm{Mg}-4.0 \mathrm{Zn}-\mathrm{xCa}$. When the $\mathrm{Ca}$ concentration increased to 2.0 wt. $\%, \mathrm{Mg}_{2} \mathrm{Ca}$, and $\mathrm{Ca}_{2} \mathrm{Mg}_{5} \mathrm{Zn}_{13}$ phases began to be detected in the alloy.

\begin{tabular}{cccccccc}
\hline \multirow{2}{*}{ Materials } & \multicolumn{7}{c}{ Chemical composition (wt.\%) } \\
\cline { 2 - 8 } & $\mathrm{Al}$ & $\mathrm{Zn}$ & $\mathrm{Mn}$ & $\mathrm{Si}$ & $\mathrm{Fe}$ & $\mathrm{Ca}$ & $\mathrm{Mg}$ \\
\hline Mg-4.0Zn & 0.023 & 3.926 & 0.058 & 0.031 & 0.004 & 0.007 & Balance \\
Mg-4.0Zn-0.2Ca & 0.033 & 1.852 & 0.030 & 0.039 & 0.007 & 0.180 & Balance \\
Mg-4.0Zn-0.5Ca & 0.029 & 2.732 & 0.022 & 0.036 & 0.007 & 0.452 & Balance \\
Mg-4.0Zn-1.0Ca & 0.019 & 3.925 & 0.021 & 0.032 & 0.008 & 0.915 & Balance \\
Mg-4.0Zn-1.5Ca & 0.027 & 5.223 & 0.031 & 0.034 & 0.009 & 1.635 & Balance \\
Mg-4.0Zn-2.0Ca & 0.024 & 5.977 & 0.019 & 0.033 & 0.012 & 2.158 & Balance \\
\hline
\end{tabular}

Table 2. Chemical composition of the as-cast $\mathrm{Mg}-4.0 \mathrm{Zn}-\mathrm{xCa}$ alloys 


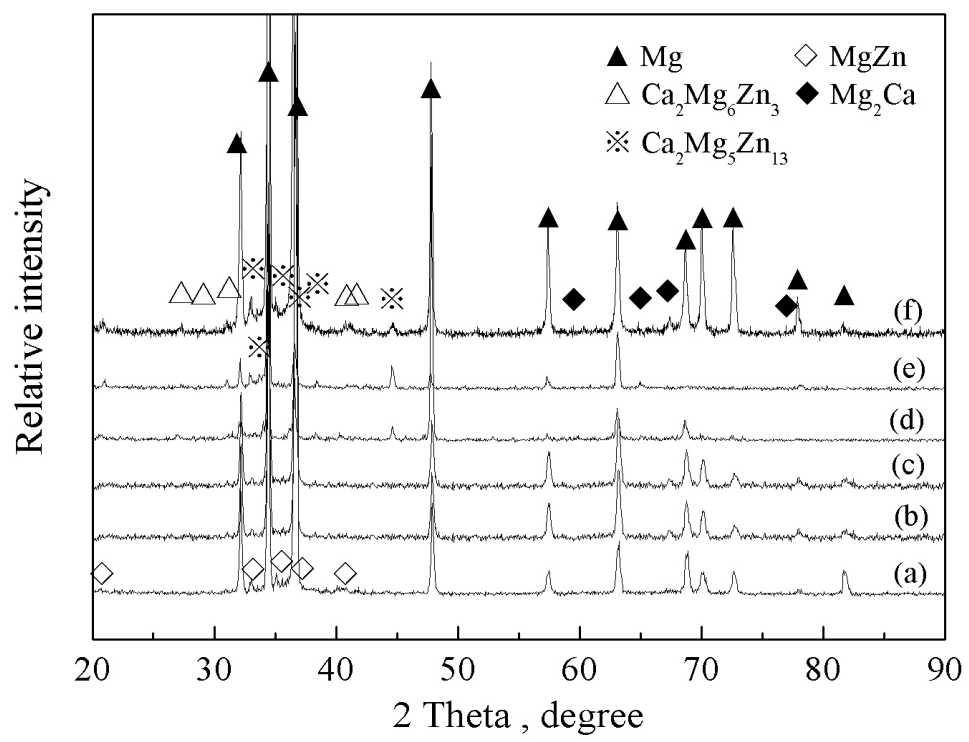

Fig. 3. XRD patterns of as-cast Mg-4.0Zn-xCa alloys (a) Mg-4.0Zn; (b) Mg-4.0Zn-0.2Ca; (c) Mg-4.0Zn-0.5Ca; (d) Mg-4.0Zn-1.0Ca; (e) Mg-4.0Zn-1.5Ca; (f) Mg-4.0Zn-2.0Ca

The microstructures of the as-cast Mg-4.0 Zn-x Ca alloys were shown in Fig.4. Fig. 4(a) was taken from the Mg-4.0 $\mathrm{Zn}$ alloy, which consisted of the dendrite a-Mg matrix and some polygonal shaped second phases which distributed in the areas of inter-dendrite and grain boundary. The second phases were very coarse in the Mg-4.0 Zn. Fig. 4(b) was taken from the Mg-4.0 Zn-0.2 Ca alloy, which indicated that the microstructure had an evidently change compared with Mg-4.0 Zn alloy, and the second phase changed its shape and distributed in the areas of inter grain. With the increase of Ca concentration, however, lamellar eutectic appeared in the as-cast microstructure, eutectic structure was mostly distributed in the grain boundary and little in the areas of inter-dendrite, as shown in Fig. 3 (e) and (f) which were taken from Mg-4.0 Zn-1.5 Ca and Mg-4.0 Zn-2.0 Ca alloys, respectively. It's easy to fond out that the morphogenesis of second phases have an obviously change by an increase in $\mathrm{Ca}$ content. At first the second phase was polygonal particles in $\mathrm{Mg}-4.0 \mathrm{Zn}$ alloy, and then when less than $0.5 \mathrm{wt}$. \% Ca was added in Mg-4.0 Zn alloy, the second phase changed its morphology, and it was small round particle. Finally when more than $0.5 \mathrm{wt}$. \% Ca was added, the second phase was lamellar structure.

In the initial stages of solidification, $\mathrm{Zn}$ and $\mathrm{Ca}$ were complete melts in the magnesium. Subsequently, as the solidification develops, the solute atoms are rejected by the growing a$\mathrm{Mg}$ and enriched in the residual liquid, which began to form clusters precipitation in the grain boundary and inter dendrite arm space. When the Ca concentration was increasing to $1.5 \mathrm{wt}$ \%, it was apt to forming lamellar eutectic. 


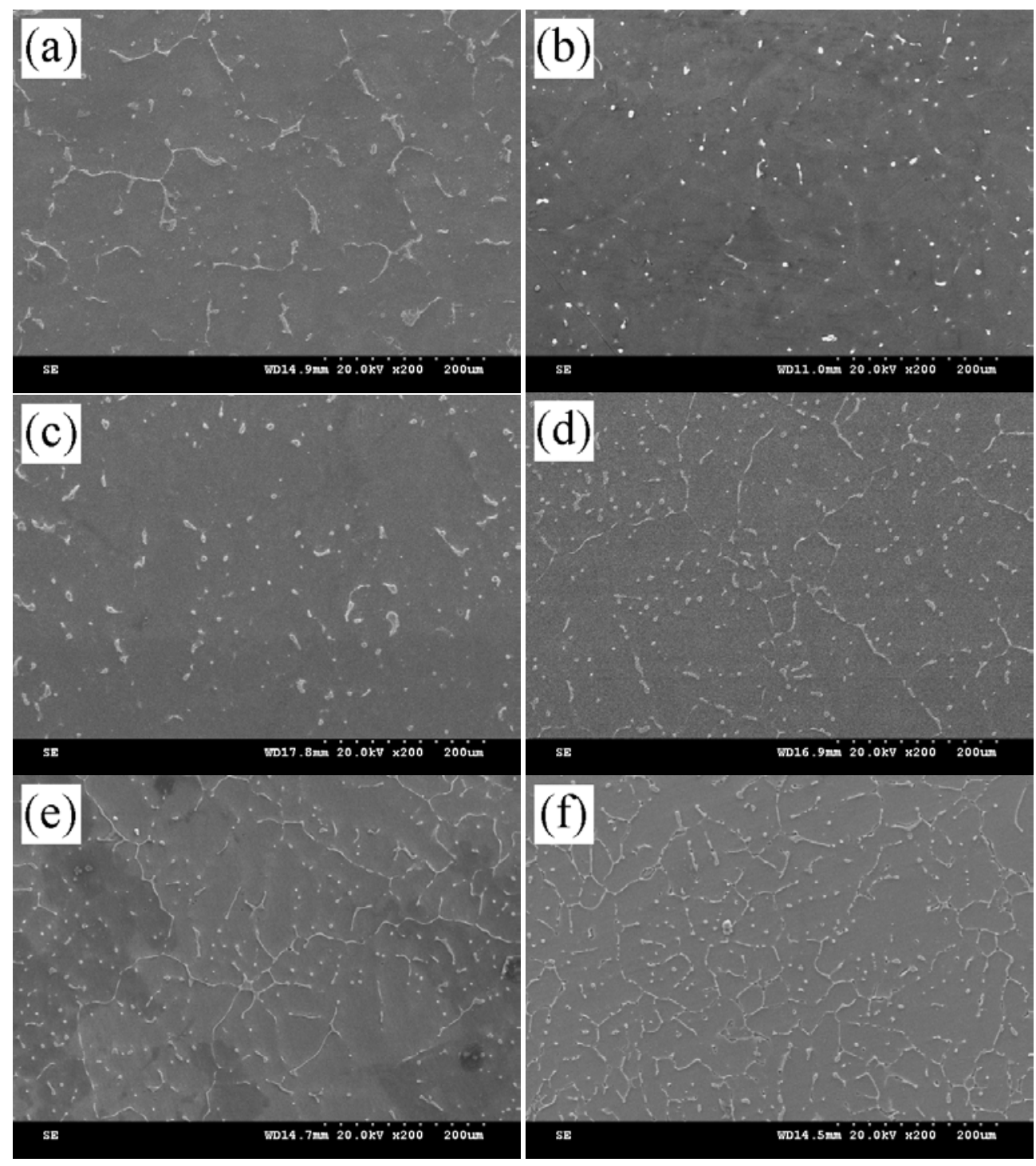

Fig. 4. Microstructure of as-cast Mg-4.0Zn-xCa alloys (a) Mg-4.0Zn; (b) Mg-4.0Zn-0.2Ca; (c) Mg-4.0Zn-0.5Ca; (d) Mg-4.0Zn-1.0Ca; (e) Mg-4.0Zn-1.5Ca; (f) Mg-4.0Zn-2.0Ca

\subsection{Mechanical property evolution of the as-cast $\mathrm{Mg}-\mathrm{Zn}$-Ca alloys}

\subsubsection{The effects of $\mathrm{Zn}$ content on mechanical property of as-cast alloys}

The tensile tests were carried out at room temperature on the as-cast $\mathrm{Mg}-\mathrm{x} \mathrm{Zn}$ alloys. The tensile strength and elongation of present alloy were shown in Table 3 . The typical stresstrain curves of Mg-x Zn alloys were depicted in Fig.5. As shown in Table 3 and Fig.5, after $1.0 \mathrm{wt} . \% \mathrm{Zn}$ was added to the pure $\mathrm{Mg}$, the mechanical properties of as-cast $\mathrm{Mg}-1.0 \mathrm{Zn}$ like 
pure $\mathrm{Mg}$ was still weak, in which the yield strength was $21 \mathrm{MPa}, \mathrm{UTS}$ was $101 \mathrm{MPa}$ and the elongation was $6.9 \%$. With the increasing of Zn contents, the yield strength, UTS and the elongation was increased. When the $\mathrm{Zn}$ content was up to $4.0 \mathrm{wt} . \%$, the mechanical properties reach to the peak value, the yield strength was $58.1 \mathrm{MPa}$, UTS was $216.85 \mathrm{MPa}$ and the elongation was $15.8 \%$. The mechanical properties of $\mathrm{Mg}-\mathrm{Zn}$ binary alloy when ulteriorly increasing of Zn contents was declined. Its UTS was $182 \mathrm{MPa}$, and its elongation was only $7.2 \%$ for $\mathrm{Mg}-6.0 \mathrm{Zn}$ alloy. Direct estimation of stacking fault energy by thermodynamic calculations showed that $\mathrm{Zn}$ reduces stacking fault energy of the $\mathrm{Mg}-\mathrm{Zn}$ alloys. Stacking fault energy is an important physical properties of the material, which directly affects the mechanical properties, dislocation cross slip, phase stability and the dynamic recrystallization of metal materials. It has been confirmed that the stacking fault energy in magnesium alloy plays an important role in mechanical properties and the dynamic recrystallization[22]

\begin{tabular}{cccc}
\hline Alloy & Yield strength(MPa) & UTS (MPa) & Elongation $(\%)$ \\
\hline Mg-1.0Zn & $20 \pm 2$ & $101.5 \pm 3$ & $6.96 \pm 0.5$ \\
Mg-2.0Zn & $27 \pm 2$ & $145.9 \pm 5$ & $12.23 \pm 1.5$ \\
Mg-3.0Zn & $47 \pm 1.5$ & $167.8 \pm 10$ & $13.7 \pm 1.0$ \\
Mg-4.0Zn & $58 \pm 1.0$ & $216.8 \pm 15$ & $15.8 \pm 5.5$ \\
Mg-5.0Zn & $68 \pm 1.5$ & $185 \pm 5$ & $9.2 \pm 0.5$ \\
Mg-6.0Zn & $69 \pm 1.5$ & $182 \pm 5$ & $7.2 \pm 0.5$ \\
\hline
\end{tabular}

Table 3. Mechanical properties of Mg-xZn alloys at room temperature

\subsubsection{The effects of Ca content on mechanical property of the as-cast alloys}

The tensile strength and elongation of as-cast Mg-4.0 Zn-x Ca alloys were shown in table 4 . The typical stress-train curves of as-cast Mg-4.0 Zn-x Ca alloys were depicted in Fig.6. The ultimate tensile strength (UTS) and elongation of as-cast $\mathrm{Mg}-4.0 \mathrm{Zn}$ alloy were $180 \mathrm{MPa}$ and 9.5\%, respectively. After $0.2 \mathrm{wt}$ \% Ca was added, the UTS and elongation of as-cast Mg- 4.0 $\mathrm{Zn}-0.2 \mathrm{Ca}$ alloy were improved to $215 \mathrm{MPa}$ and $17.5 \%$, respectively. When $0.5 \mathrm{wt}$. \% Ca was added, the Mg-4.0 Zn-0.5 Ca alloy has similar mechanical property as the Mg- $4.0 \mathrm{Zn}-0.2 \mathrm{Ca}$ alloy. However, the mechanical properties of as-cast Mg-4.0 Zn-1.0 Ca alloy began to decline. When the Ca concentration was up to $2.0 \mathrm{wt}$. \%, the alloy showed worse mechanical property, its UTS was $142 \mathrm{MPa}$ and elongation was only $1.7 \%$.

Fig.7 showed the typical fracture surfaces of as-cast Mg-4.0 Zn-x Ca alloys. As it was showed that the fracture type was ductile fracture when Ca concentration was lower than 0.5 wt. \%. Big dimples and tearing edges can be evidently observed on the fracture surface of the as-cast Mg-4.0 Zn-0.2 Ca (Fig.8 (a)).When the Ca concentration was 1.0 wt. \%, the Mg4.0 Zn-1.0 Ca alloy showed mixture fracture morphology. When the Ca concentration was up to $2.0 \mathrm{wt}$. \%, the fracture type of the alloy was brittle fracture. The pearl-shaped fracture can be easily observed on the fracture surface of the as-cast Mg-4.0 Zn-2.0 Ca alloy (Fig. 5 (c)). 


\begin{tabular}{cccc}
\hline Alloy & Yield strength (MPa) & UTS (MPa) & Elongation (\%) \\
\hline Mg-4.0Zn & $58 \pm 1.0$ & $216.8 \pm 15$ & $15.8 \pm 5.5$ \\
Mg-4.0Zn-0.2Ca & $58.1 \pm 1.0$ & $225 \pm 5$ & $17.5 \pm 1.0$ \\
Mg-4.0Zn-0.5Ca & $70 \pm 3.0$ & $180 \pm 5$ & $12.3 \pm 1.5$ \\
Mg-4.0Zn-1.0Ca & $83 \pm 2.0$ & $175 \pm 10$ & $8.7 \pm 1.0$ \\
Mg-4.0Zn-1.5Ca & $83 \pm 3.0$ & $167 \pm 5$ & $7.1 \pm 2.5$ \\
Mg-4.0Zn-2.0Ca & $90 \pm 4.0$ & $143 \pm 5$ & $2.1 \pm 0.5$ \\
\hline
\end{tabular}

Table 4. Mechanical properties of Mg-4.0wt. $\% \mathrm{Zn}-\mathrm{xCa}$ alloys at room temperature

The mechanical properties of magnesium were affected by each alloying constituent. Zinc was an effective alloying ingredient in magnesium. Because zinc had a relatively high solid solubility in magnesium at high temperature, a good mechanical properties were achieved by solid solution strengthen. Binary $\mathrm{Mg}-\mathrm{Zn}$ alloys like $\mathrm{Mg}-\mathrm{Al}$ alloys, also respond to age hardening, and contrary to $\mathrm{Mg}-\mathrm{Al}$ alloys, coherent GP zone and semeicoherent intermediate precipitate were formed to have an enhanced effect. However, in the $\mathrm{Mg}-\mathrm{Zn}$ alloys, the maximum solubility of zinc in the magnesium drops to $1.6 \mathrm{wt}$ \% (i.e. 0.6 at. \%) at room temperature in the equilibrium state [23]. When the zinc content was more than $4.0 \mathrm{wt} \%$, in the solidification process, the melt zinc atoms would be rejected by the growing a-Mg and enriched in the residual liquid, these rich areas were often prone to formation of microporosity.

In $\mathrm{Mg}$ - Zn alloys, the progressive addition of $\mathrm{Ca}$ had been found to substantially increase the temperature difference between liquid and solid phase lines, which was conducive to the grain refinement in the solidification process. At the same time, the introduction of Ca to $\mathrm{Mg}-\mathrm{Zn}$ alloys result in precipitation of desolventizing phase, Ca2Mg6Zn3 and Ca2Mg5Zn13, which could enhance the strength and toughness of alloy [24][25][26]. The current work showed that an addition of small amount of $\mathrm{Ca}$ to $\mathrm{Mg}-4.0 \mathrm{Zn}$ alloys had a marked increase in the tensile strength, but Ca content was excess of $0.5 \mathrm{wt}$. \% make the tensile strength prone to decrease. The precipitates in the Mg-4.0 Zn-0.2 Ca and Mg-4.0 Zn-0.5 Ca alloys were Ca2Mg6Zn3 and Ca2Mg5Zn13 phases, which were small particles in the alloys. Thus, the tensile property of $\mathrm{Mg}-4.0 \mathrm{Zn}-0.2 \mathrm{Ca}$ and $\mathrm{Mg}-4.0 \mathrm{Zn}-0.5 \mathrm{Ca}$ alloys were improved. However, the maximum solubility of $\mathrm{Ca}$ in the magnesium was only $0.2 \mathrm{wt}$. \% at room temperature and $1.2 \mathrm{wt} . \%$ at high temperature in the equilibrium state, when more than 1.0 wt. \% Ca was added, the precipitates in the grain boundary began to continuously precipitated and the morphogenesis of the precipitates were changed to lamellar structure, made the tensile properties decline. When the Ca concentration was up to $2.0 \mathrm{wt}$. \%, in the grain boundary tends to form eutectic structure which caused the tensile property deteriorate.

\subsection{In-vitro degradation tests}

\subsubsection{The effects of $\mathrm{Zn}$ content on in-vitro degradation of the as-cast alloys}

The representative potentiodynamic polarization curves of $\mathrm{Mg}-\mathrm{xZn}$ alloys in Hank's solution were shown in Fig.8, with pure $\mathrm{Mg}$ as contrast. As shown in Fig.8, the corrosion potential of the $\mathrm{Mg}-\mathrm{x} \mathrm{Zn}$ alloys was higher than that of pure $\mathrm{Mg}$. The corrosion potential of 
pure $\mathrm{Mg}$ was $-1574 \mathrm{mV}$. The corrosion potential was correlated with the $\mathrm{Zn}$ concentration. The corrosion potential of $\mathrm{Mg}-2.0 \mathrm{Zn}$ and $\mathrm{Mg}-3.0 \mathrm{Zn}$ alloys were about -1561 and $-1568 \mathrm{mV}$, respectively, which were nearly the same and about $10 \mathrm{mV}$ high than that of pure $\mathrm{Mg}$. The Mg-5.0 Zn and Mg-6.0 Zn alloy samples exhibit high corrosion potentials of about -1524 and $-1547 \mathrm{mV}$, respectively, which were about $50 \mathrm{mV}$ higher than that of pure $\mathrm{Mg}$. It could be seen that the addition of $\mathrm{Zn}$ improved the corrosion potential of the as-cast $\mathrm{Mg}-\mathrm{x} \mathrm{Zn}$ alloys. But, the addition of elements $\mathrm{Zn}$ was also increased the current densities of the resulted ascast $\mathrm{Mg}$ alloys in Hank's solution.

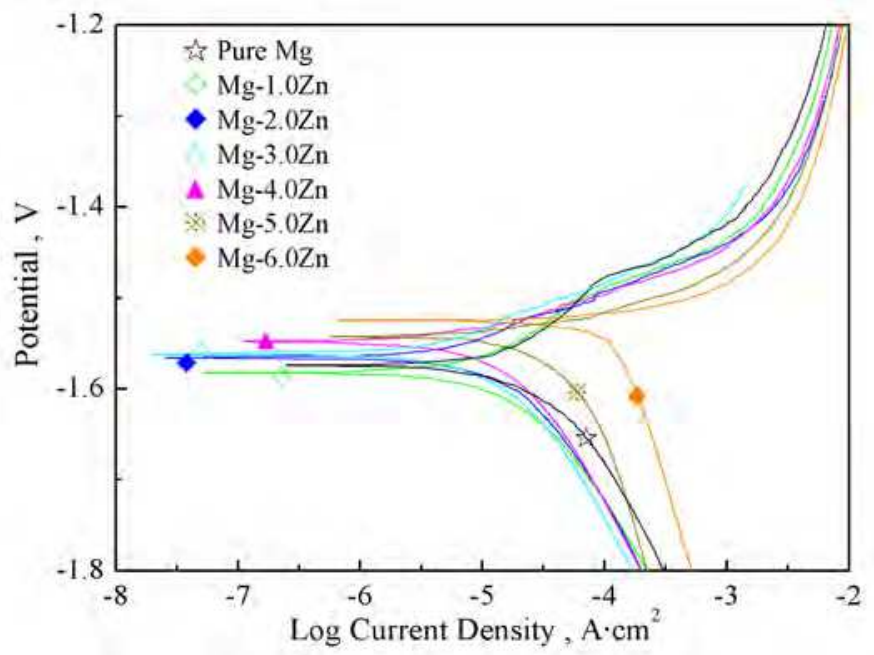

Fig. 8. Potentiodynamic polarization curves of Mg-Zn alloys in SBF solution

The reason for the increase corrosion potential of Mg-x $\mathrm{Zn}$ alloys was that the $\mathrm{Zn}$ element had a high electronegative. But, when the $\mathrm{Zn}$ concentration increased, the corrosion resistance was decreased. The reason for the reduced corrosion resistance of Mg-x $\mathrm{Zn}$ alloys was that the second phase precipitated during the solid solidification processes, which accelerated the corrosion rate due to the different electrochemical behaviors of a-Mg and precipitates.

Generally, the cathodic polarization curves were assumed to represent the cathodic hydrogen evolution through water reduction, while the anodic polarization curves represented the dissolution of magnesium. It could be seen that the cathodic polarization current of hydrogen evolution reaction on $\mathrm{Mg}-1.0 \mathrm{Zn}$ alloy sample was much lower than that of Mg-5.0 Zn and Mg-6.0 Zn Ca alloys sample, suggesting that over potential of the cathodic hydrogen evolution reaction was lower for $\mathrm{Mg}-1.0 \mathrm{Zn}$ and $\mathrm{Mg}-2.0 \mathrm{Zn}$ alloys sample. As a result, the cathodic reaction was kinetically more difficult on the Mg-1.0 Zn alloy and $\mathrm{Mg}-2.0 \mathrm{Zn}$ alloy sample than that on the Mg-5.0 $\mathrm{Zn} \mathrm{Ca}$ alloy samples. The degradation rates of $\mathrm{Mg}-1.0 \mathrm{Zn}$ degraded were slower thanMg-5.0Zn, Mg-6.0Zn, which was adherence to the electrochemical results.

\subsubsection{The effects of Ca content on in-vitro degradation of the as-cast $\mathrm{Mg}-\mathrm{Zn}-\mathrm{Ca}$ alloys}

The representative potentiodynamic polarization curves of the pure $\mathrm{Mg}$ and $\mathrm{Mg}-4.0 \mathrm{Zn}-\mathrm{x} \mathrm{Ca}$ alloys in Hank's solution were shown in Fig.9. The mean corrosion potentials of Mg-4.0Zn- 
$\mathrm{xCa}$ alloys are enhanced to $-1574 \mathrm{mV}$, which is increased by $70 \mathrm{mV}$ compared with $-1646 \mathrm{mV}$ of the pure $\mathrm{Mg}$ corrosion potential. However, it is confirmed that Mg- $4.0 \mathrm{Zn}-0.2 \mathrm{Ca}$ alloy exhibits the best corrosion resistance among $\mathrm{Mg}-4.0 \mathrm{Zn}-\mathrm{xCa}$ alloys, even higher than that of $\mathrm{Mg}-4.0 \mathrm{Zn}$ alloy through further observation. This particular phenomenon can be explained as follows. Firstly, the addition of $4.0 \mathrm{wt}$. \% $\mathrm{Zn}$ can cause the formation of coarse MgZn precipitate as shown in Fig.4 and 2(a), which reduces the corrosion resistance of Mg-4.0Zn alloy due to the different electrochemical behaviors between primary a-Mg and precipitate. Then, the slight addition (less than 0.5 wt. \%) of Ca alloying element can cause MgZn precipitates to be effectively transform to fine ternary precipitates, which has been clearly documented in previous literature [27][28]. The refinement and homogenization of precipitate phase can improve the corrosion resistance of $\mathrm{Mg}-4.0 \mathrm{Zn}-0.2 \mathrm{Ca}$ alloy compared with that of $\mathrm{Mg}-4.0 \mathrm{Zn}$ alloy. Finally, increasing Ca content was over than $0.5 \mathrm{wt}$. \% cause the formation of another coarse $\mathrm{Mg}_{2} \mathrm{Ca}, \mathrm{Ca}_{2} \mathrm{Mg}_{6} \mathrm{Zn}_{3}$ and $\mathrm{Ca}_{2} \mathrm{Mg}_{5} \mathrm{Zn}_{13}$ precipitates as shown in Fig. 3 and 4. It is quite obvious that the precipitates increases with $\mathrm{Ca}$ content increasing, which decreases the corrosion resistance of as-cast $\mathrm{Mg}-4.0 \mathrm{Zn}-\mathrm{xCa}$ alloys.

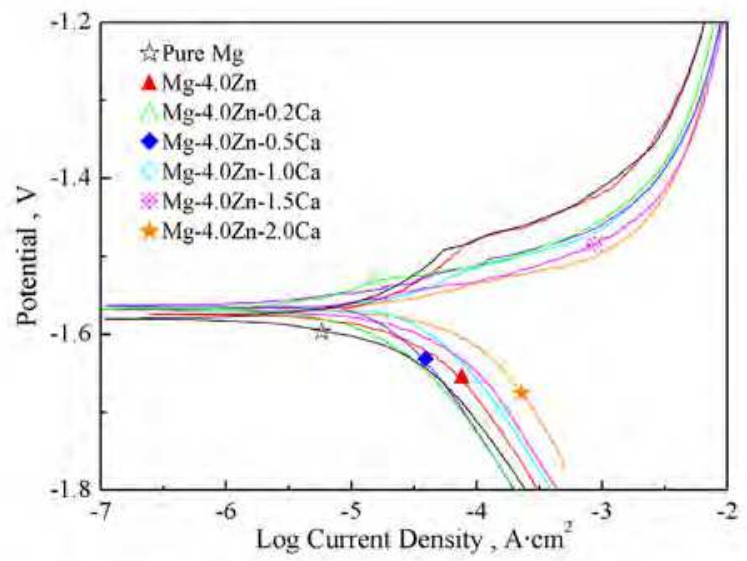

Fig. 9. The potentiodynamic polarization curves of as-cast Mg-4.0 Zn-x Ca alloys in Hank's solution.

It is well known that the cathodic polarization curves represent the cathodic hydrogen evolution through water reduction, while the anodic polarization curves do the dissolution of magnesium. That is to say, it is equivalent to that Mg- $4.0 \mathrm{Zn}-0.2 \mathrm{Ca}$ alloy sample exhibits the lowest current of hydrogen evolution reaction and Mg-4.0 Zn-1.5 Ca and Mg-4.0Zn-2.0 Ca alloys samples does the highest ones, which indicates that over potential of the cathodic hydrogen evolution reaction of $\mathrm{Mg}-4.0 \mathrm{Zn}-0.2 \mathrm{Ca}$ alloy is much lower than those of $\mathrm{Mg}-4.0$ $\mathrm{Zn}-1.5 \mathrm{Ca}$ and Mg-4.0 Zn-2.0 Ca alloys. Therefore, the lowest cathodic hydrogen evolution reaction brings the highest corrosion resistance to the Mg-4.0 Zn-0.2 Ca alloy.

Fig.10 illustrates the $\mathrm{pH}$ variation of Hank's solution versus the immersion testing time for $\mathrm{Mg}-4.0 \mathrm{Zn}-\mathrm{xCa}$ alloys. It could be observed that the $\mathrm{pH}$ variations of the alloys all obey the parabolic rate law. The $\mathrm{pH}$ variation rate decreases with the immersion time increasing. After $48 \mathrm{hrs}$ immersion, all the $\mathrm{pH}$ values of the samples tend to be stable. In the early period of immersion, both pure $\mathrm{Mg}$ and the $\mathrm{Mg}-4.0 \mathrm{Zn}-\mathrm{xCa}$ alloys acutely reacted with 
Hank's solutions and rapidly generated bubbles. And these reactions of $\mathrm{Mg}$ and $\mathrm{H}_{2} \mathrm{O}$ in Hank's solution generated a large amount of $\mathrm{OH}^{-}$and leaded to the $\mathrm{pH}$ values of the solutions be obviously increased. Comparing the $\mathrm{pH}$ values of $\mathrm{Mg}-4.0 \mathrm{Zn}-\mathrm{xCa}$ alloys, it can be found that the $\mathrm{pH}$ variations of pure $\mathrm{Mg}$ and $\mathrm{Mg}-4.0 \mathrm{Zn}-0.2 \mathrm{Ca}$ alloy are much lower than those of $\mathrm{Mg}-4.0 \mathrm{Zn}-1.5 \mathrm{Ca}$ and $\mathrm{Mg}-4.0 \mathrm{Zn}-2.0 \mathrm{Ca}$ alloys. The $\mathrm{pH}$ values of $\mathrm{Mg}-4.0 \mathrm{Zn}-1.5 \mathrm{Ca}$ and $\mathrm{Mg}-4.0 \mathrm{Zn}-2.0 \mathrm{Ca}$ alloys are remarkably increased to 8.2 from 7.4 after $12 \mathrm{hrs}$ immersion tests, which is even equal to those of pure $\mathrm{Mg}$ and $\mathrm{Mg}-4.0 \mathrm{Zn}-0.2 \mathrm{Ca}$ alloy after $96 \mathrm{hrs}$ immersion tests. At the end of the immersion tests, the $\mathrm{pH}$ values are increased to 8.22 and 8.32 for pure $\mathrm{Mg}$ and $\mathrm{Mg}-4.0 \mathrm{Zn}-0.2 \mathrm{Ca}$ alloy, respectively. In particular, the $\mathrm{pH}$ value is elevated to 11 from 7.4 for $\mathrm{Mg}-4.0 \mathrm{Zn}-2.0 \mathrm{Ca}$ alloy. This phenomenon can be explained as follows. The standard potential of coarse second phases of $\mathrm{Mg}-4.0 \mathrm{Zn}-1.5 \mathrm{Ca}$ and $\mathrm{Mg}-4.0 \mathrm{Zn}-2.0 \mathrm{Ca}$ alloys is higher than that of the pure $\mathrm{Mg}$. Therefore, the selective attack occurred between $\mathrm{a}-\mathrm{Mg}$ and the second phase, and the reaction in Hank's solutions is acute. Thus, the $\mathrm{pH}$ values of $\mathrm{Mg}$ $4.0 \mathrm{Zn}-1.5 \mathrm{Ca}$ and $\mathrm{Mg}-4.0 \mathrm{Zn}-2.0 \mathrm{Ca}$ alloys are rapidly increased. However, the uniform microstructure and lower reaction rates of pure $\mathrm{Mg}, \mathrm{Mg}-4.0 \mathrm{Zn}-0.2 \mathrm{Ca}$ and $\mathrm{Mg}-4.0 \mathrm{Zn}-0.5 \mathrm{Ca}$ alloys cause a slow increase of $\mathrm{pH}$ values. After $48 \mathrm{hrs}$ immersion, bubbles are quite decreased which corresponds a slow reaction rate and leads a slow increase of the $\mathrm{pH}$ values for the samples. In addition, the increasing corrosion films including HA and other phosphates formed by the reaction during the immersion test can further reduce the reaction rates or degradation of the alloys [29].

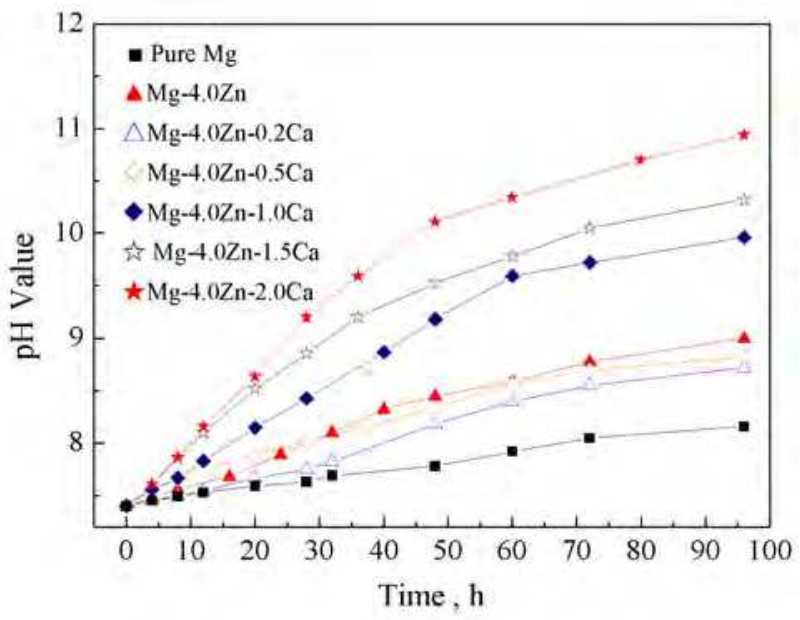

Fig. 10. $\mathrm{pH}$ variation of Hank's solution versus the immersion testing time for as-cast Mg4.0Zn-xCa alloys.

According to the above-mentioned search, we found that $\mathrm{Mg}-4.0 \mathrm{Zn}-0.2 \mathrm{Ca}$ alloy have an excellent corrosion resistance among the $\mathrm{Mg}-\mathrm{Zn}$ and the $\mathrm{Mg}-\mathrm{Zn}-\mathrm{Ca}$ alloys. Thus, the immersion test was only performance on the $\mathrm{Mg}-4.0 \mathrm{Zn}-0.2 \mathrm{Ca}$ alloy. The degradation rates of the alloy after 30-day immersion were listed in Table 5. The degradation rates of Mg-4.0Zn$0.2 \mathrm{Ca}$ alloy degraded were slower than pure $\mathrm{Mg}$, which was adherent to the electrochemical results. 
$\mathrm{Mg}$ and the Mg-4.0Zn-0.2Ca alloy degraded quickly, during the early stage of immersion in $\mathrm{SBF}$, accompanied by the rapid formation of an insoluble protective corrosion layer, which retarded degradation. The degradation process of $\mathrm{Mg}-4.0 \mathrm{Zn}-0.2 \mathrm{Ca}$ alloy could be roughly summarized as follows: just after immersion in SBF solution, magnesium alloy react with fluids on the surface and get dissolved in the surrounding fluids. With the increasing time of immersion, more $\mathrm{Mg}^{2+}, \mathrm{Zn}^{2+}$ and $\mathrm{Ca}^{2+}$ ions were dissolved into the solution, the local $\mathrm{pH}$ near the surface of the $\mathrm{Mg}$ could be $>10[30]$. As a result, a magnesium-containing calcium phosphate would precipitate from the SBF solution and deposited on the surface of the magnesium samples, per the following equation:

Anodic reaction:

$$
\mathrm{Mg} \rightarrow \mathrm{Mg}^{+2}+2 e
$$

Cathodic reaction:

$$
\begin{gathered}
2 \mathrm{H}_{2} \mathrm{O}+2 e \rightarrow \mathrm{H}_{2}+2 \mathrm{OH}^{-} \\
\mathrm{Mg}^{+2}+2 \mathrm{OH}^{-} \rightarrow \mathrm{Mg}(\mathrm{OH})_{2} \\
\mathrm{PO}_{4}^{3-}+\mathrm{Ca}^{2+}+\mathrm{Mg}^{2+} \rightarrow \mathrm{Mg}_{x} \mathrm{Ca}_{y}\left(\mathrm{PO}_{4}\right)
\end{gathered}
$$

Moreover, when $\mathrm{Mg} 2+, \mathrm{Zn} 2+$ and $\mathrm{Ca} 2+$ ions were dissolved into the solution, phosphatecontaining $\mathrm{Mg} / \mathrm{Ca}$ insoluble protective layer was formed and tightly attached to the matrix. Previous studies [31] have shown that this corrosion layer promotes the osteo-inductivity and osteo-conductivity, predicting good biocompatibility of magnesium and retarded degradation. Therefore, it is proposed that the $\mathrm{Mg}^{2+}, \mathrm{Zn}^{2+}$ and $\mathrm{Ca}^{2+}$ released during degradation are safe. Hence, we come to the conclusion that the degradation of the $\mathrm{Mg}$ 4.0Zn-0.2Ca alloy was harmless and has good biocompatibility.

\begin{tabular}{cccc}
\hline & $\mathrm{E}(\mathrm{V})$ & Current $\left(\mathrm{mA} / \mathrm{cm}^{2}\right)$ & $\mathrm{V}(\mathrm{mm} /$ year $)$ \\
\hline As-cast & -1.60 & 2.67 & 2.05 \\
Extruded & -1.57 & 2.43 & 1.98 \\
\hline
\end{tabular}

Table 5. Corrosion potential, corrosion current and corrosion rate of $\mathrm{Mg}-4.0 \mathrm{Zn}-0.2 \mathrm{Ca}$ alloys

\subsubsection{Corrosion morphology and products}

The samples after electrochemical measurements were observed by SEM. The typical Surface morphology of $\mathrm{Mg}-\mathrm{Zn}-\mathrm{Ca}$ alloys after electrochemical measurements was shown in Fig.11. Corrosion attack on a large area was observed. At the same time, the filiform corrosion and pitting corrosion were found on the Mg-Zn-Ca alloys sample's surface after electrochemical measurements. The former mainly distributed on the grain boundary, and the latter mostly occurred in second phase location.

XRD patterns of the corrosion products on the surface of $\mathrm{Mg}-\mathrm{Zn}$-Ca alloys immersed in Hank's solution were presented in Fig.12. The XRD results suggest that magnesium hydroxide $\left[\mathrm{Mg}(\mathrm{OH})_{2}\right]$, other phosphates and hydroxyapatite (HA) were precipitated on the $\mathrm{Mg}-\mathrm{Zn}-\mathrm{Ca}$ alloys surface. 

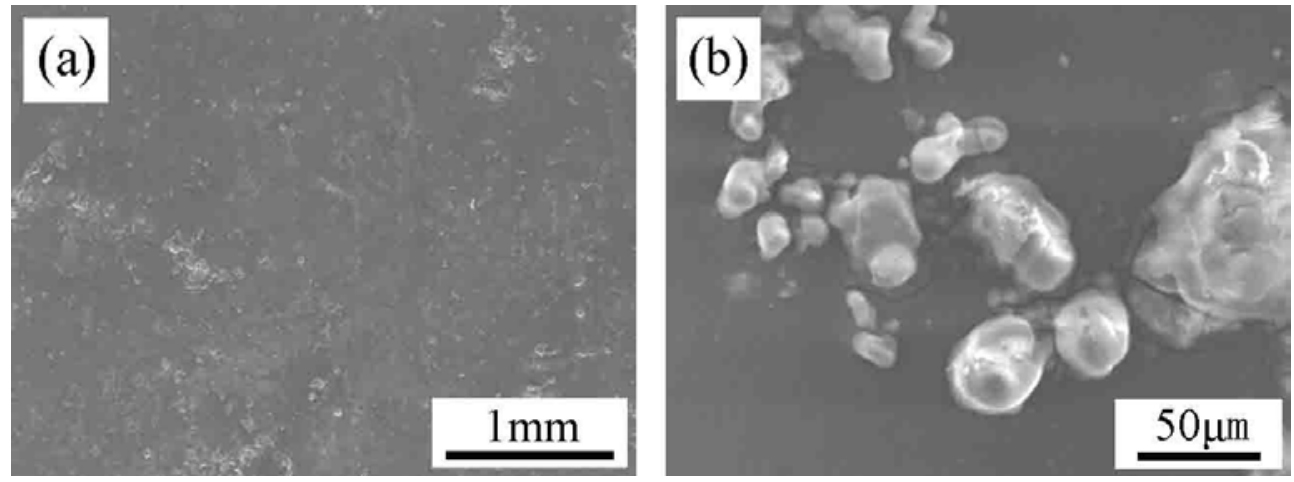

Fig. 11. The typical surface morphology of Mg-4.0 Zn-0.2 Ca alloy after electrochemical measurements: (a) macrostructure (b) microstructure

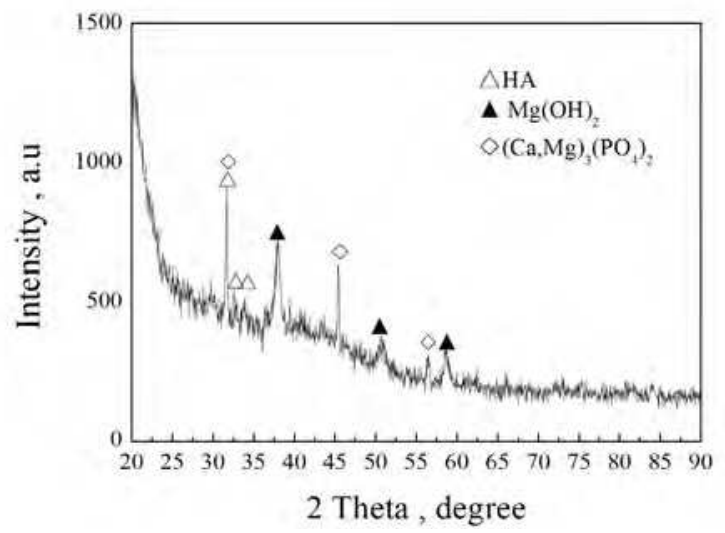

Fig. 12. XRD patterns of the corrosion products of Mg-4.0 Zn-0.2 Ca alloy immersed in Hank's solution.

\subsection{Cytotoxicity assessments}

The $\mathrm{pH}$ values of the extraction medium were measured, and only the values of $\mathrm{Mg}-1.0 \mathrm{Zn}$, Mg-2.0 Zn, Mg-3.0 Zn, Mg-4.0 Zn, Mg-4.0 Zn-0.2 Ca and Mg-4.0 Zn-0.5 Ca alloys were below than 8.0. That's mean all of these alloys have a potential probability used as the biomaterials. As the economic reason, only Mg-4.0 Zn-0.2 Ca was selected to evaluate the cytotoxicity through examining both the viability and morphology of L-929 cells in this study.

The morphologies of L-929 cells cultured in different extracts after 7 day incubation were shown in Fig.13. It could be seen that the cell morphologies in different extracts were normal and healthy, which was similar to that of the negative control. Fig.14 shows the RGR of L929 cells after 2, 4 and 7 days of incubation. There was no significant difference between the RGR of cells in the extracts and those in the negative control. According to standard ISO 10993-5: 1999 [32], the cytotoxicity of these extracts was Grade 0-1. In other words, the Mg$4.0 \mathrm{Zn}-0.2 \mathrm{Ca}$ alloy has a level of biosafety suitable for in cellular applications. 


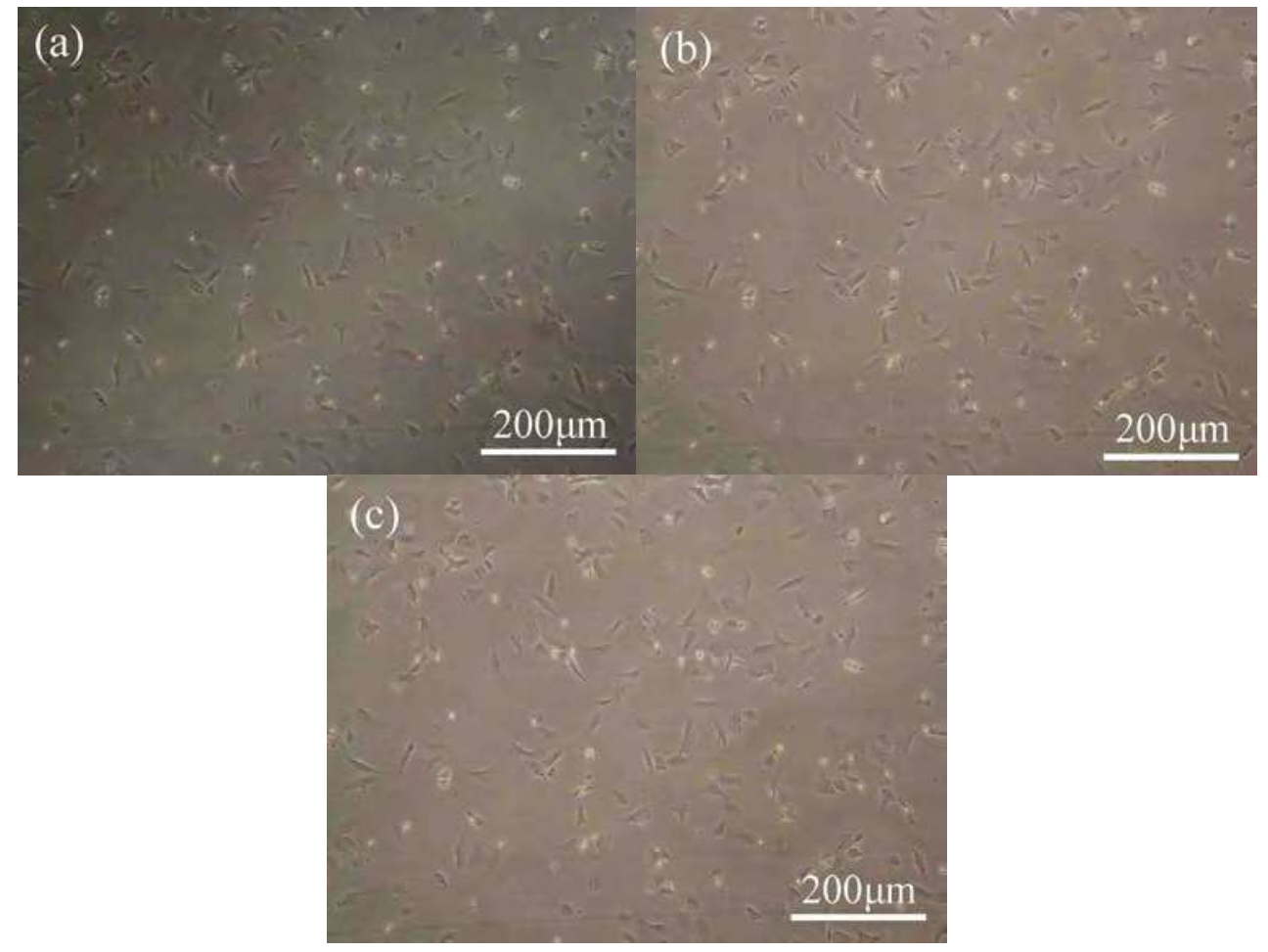

Fig. 13. Morphologies of L-929 cells cultured for 7 day in different extraction media:(a) Negative control, (b) as-cast, (c) extruded.

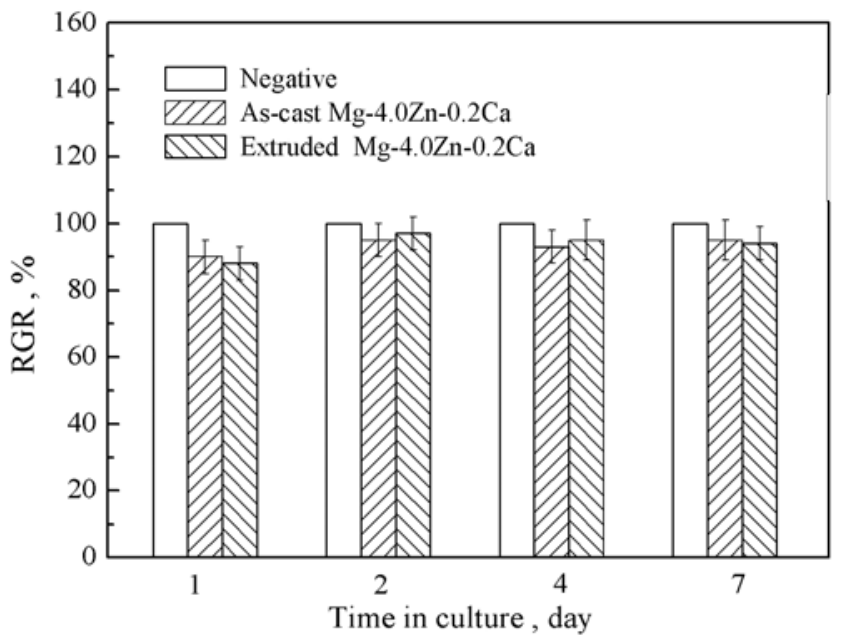

Fig. 14. Cell viability cultured in 100\% extraction medium for 1, 2, 4 and 7 days. 
The MTT tests were widely used cytotoxicity tests because they are easy, fast and cheap. But, in the case of $\mathrm{Mg}$ materials, the use of these test kits leads to false positive or false negative results. It is conceivable that $\mathrm{Mg}$ in the highly alkaline environment may be able to open the ring form of the tetrazolium salt and bind to it, which could lead to a change in colors similar to the formation of formazan in the case of the MTT tests with cells [20]. Thus the results of cytotoxicity tests conducted by MTT test will be higher than the true story. It is well known that the neutral red assay and the MTT assay exhibited almost identical reaction patterns for most test materials in L929 cells [33]. Thus, in this study, the neutral red kits were used to assay the cytotoxicity. Its measurement principle is based on the uptake of the vital dye neutral red into lysosomes of viable cells. Neutral red is accumulated because of the low intravesicular $\mathrm{pH}$ value. Lysosomes are, however, only one type of subcellular compartments which are acidified by ATP-driven proton pumps (V-type ATPase) and related low intravesicular pH value across vesicle membranes [34]. Accumulation of neutral red in acidic intracellular vesicles needs both ATP as a universal metabolic energy source for proton translocation against an electrochemical $\mathrm{H}^{+}$-gradient and tightly sealed vesicle membrane to maintain potential differences. In an alkaline environment with $\mathrm{Mg}^{2+}$, neutral red could lead to a change in color to yellow. But, the uptake of the vital dye neutral red into lysosomes was red color. The preliminary results of this test show that it seems not to be influenced by corroding $\mathrm{Mg}$. Therefore, the neutral red assay may be regarded as a valid alternative method to determine cell viability, as it shows no interference with the corroding materials. The in-vitro cytotoxicity of $\mathrm{Mg}-4.0 \mathrm{Zn}-0.2 \mathrm{Ca}$ alloy was found to be Grade $0-1$, indicating that the alloy was bio-safe.

\subsection{In-vivo degradation}

Furthermore, in order to further study the biocompatibility of $\mathrm{Mg}-4.0 \mathrm{Zn}-0.2 \mathrm{Ca}$ alloy, the invivo test was conducted on this new type magnesium alloy. Fig.15 showed the optical images of the cross-section of bone and magnesium implants after 3 months implantation. It could be seen that all the shapes of the magnesium implant had been changed from rod shape to irregular shape, indicating the implant was corroded by the body fluid, or the implant degraded in the body fluid. Meanwhile, a degradation layer or a reaction layer could be clearly found on the surface of the alloy implant, as indicated by D in Fig.15. In addition, newly formed bone was observed between the degradation layer and bone tissue around the magnesium alloy implants, as shown by $\mathrm{N}$ in Fig.15. The degradation rate was calculated according to the ratios of the cross section area of the residual implant to the original implant. After 3 months implantation, about 35-38\% Mg-4.0Zn-0.2Ca alloy implant was degraded. Significant difference $(\mathrm{p}<0.05)$ in the in-vivo degradation rates was observed.

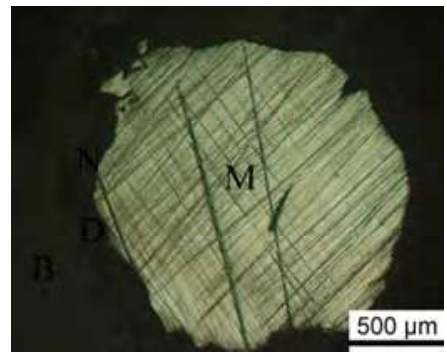

Fig. 15. Optical images of the cross-sections of Mg-Zn-Ca implants and bones after 3 months post implantation (M, metal; $\mathrm{D}$, degradation layer; $\mathrm{N}$, new bone; $\mathrm{B}, \mathrm{bone}$ ). 
Fig.16 showed a high magnification microstructure of the bone implant interface after 3 months implantation by SEM. It could be clearly seen that the degradation layer was not dense, and many cracks were found. In order to reveal the chemical composition of the degradation layer, EDS was used to analyze the chemical composition of interface. The results were shown in Fig.16 (b). From the analysis results, it could be figured out that the degradation layer was mainly composed of carbon, oxygen, magnesium, calcium and phosphorous. However, the chemical composition was not homogeneous through the whole layer. At the position close to the $\mathrm{Mg}$ implant side, higher calcium content and higher $\mathrm{Ca} / \mathrm{P}$ ratio were found. At the position close to the bone side, the calcium content was still high, but the $\mathrm{Ca} / \mathrm{P}$ ratio became much smaller compared with at the position close to the $\mathrm{Mg}$ implant side. However, there was a sharp change in $\mathrm{Mg}$ content at the interface.
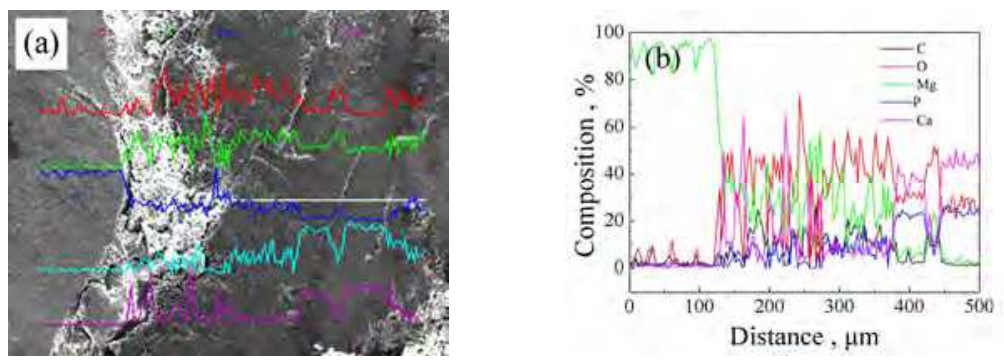

Fig. 16. (a) SEM microstructure of the interface between magnesium implant and bone interface after3 month post implantation, (b) EDS analysis patterns of implant and bone interface after 3 months post implantation.

\subsection{Histological analysis}

Fig.17 showed the tissue response to the $\mathrm{Mg}-4.0 \mathrm{Zn}-0.2 \mathrm{Ca}$ alloy pins implantation at 1,2 and 3 months. It could be clearly seen that some lymphocytes were identified in histological tissue in 1 month after operation, but there was no visible evidence of multinucleated giant cells. After 2 months implantation, there was an active bone formation, which was evident by large number of new disorganized trabeculae. After 3 months implantation, new bone tissue was formed around the magnesium implant. In comparison with the histological microstructure obtained at the cortical bone near the implantation site, as shown in Fig.17, no difference could be found in the histological microstructure between the new bone and the cortical bone.

Magnesium alloys have attracted much attention as potential biodegradable bone implant materials due to their biodegradability in the bioenvironmental as well as their excellent mechanical properties such as high strength and an elastic modulus close to that of bone. In this paper, the in-vitro cytotoxicity and in-vivo biocompatibility of new kind of Mg-4.0Zn$0.2 \mathrm{Ca}$ alloy was studied. The cytotoxicity test indicated that the $\mathrm{Mg}-4.0 \mathrm{Zn}-0.2 \mathrm{Ca}$ alloy had no cytotoxicity. Rabbit implantation indicated that the $\mathrm{Mg}-4.0 \mathrm{Zn}-0.2 \mathrm{Ca}$ alloy did not cause any inflammation reaction. One month after operation, all magnesium implants were fixed tightly. There was no gap between the bone and the residual implant. Optical images from Fig.15 and SEM microstructure from Fig.16 showed clearly that there was a degradation layer formed on the surface of the magnesium implants. Histological images showed that new bone tissue was in contact with the magnesium implant through this degradation layer. 
Line scanning in Fig.17 proved that large amount of $\mathrm{Ca}$ and $\mathrm{P}$ was found around the magnesium implant. In the present study, the histological analyses revealed that this magnesium-containing calcium phosphate degradation layer could promote or accelerate the new bone formation.
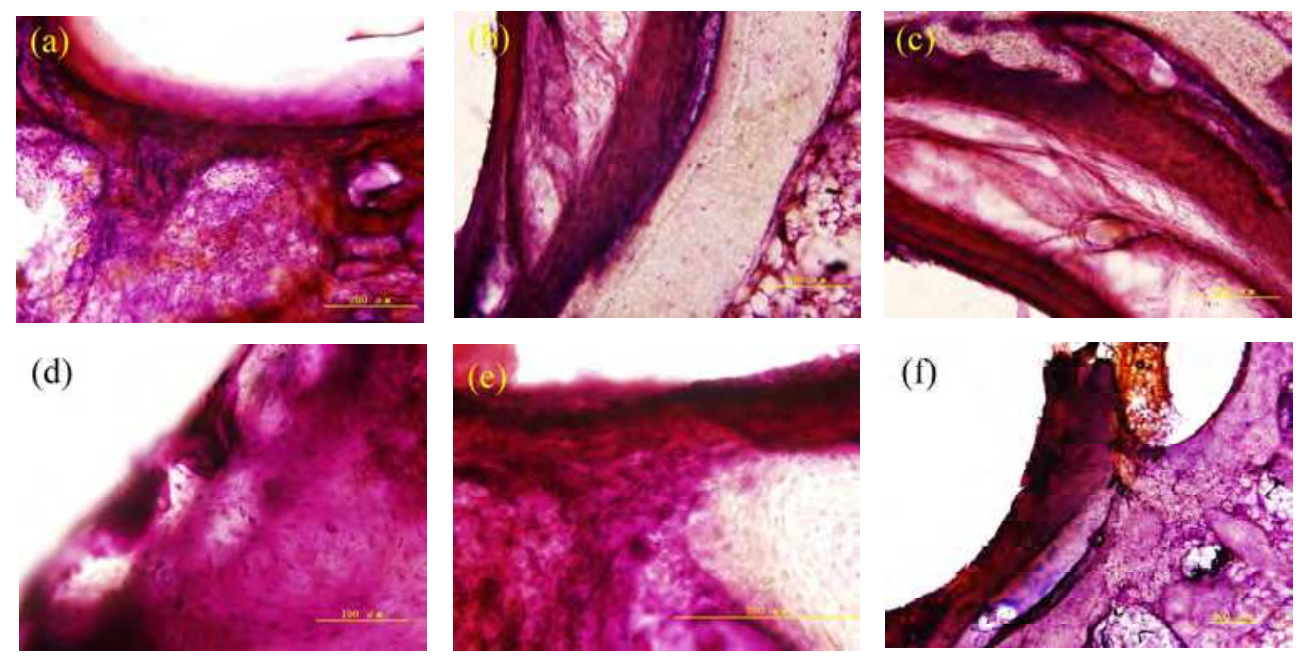

Fig. 17. Tissue response of the Mg-Zn-Ca alloy implantation at 1, 2 and 3 months (a) Mg4.0Zn-0.2Ca 1 month, (b) Mg-4.0Zn-0.2Ca 2 month, (c) Mg-4.0Zn-0.2Ca 3 month, (d) cortical bone.

In-vivo degradation was a very complex process, so it was difficult to accurately assess the degradation rate of an implant material. F. Witte et al [35] found that the corrosion of a magnesium rod in the medullar cavity was not homogeneous in all cross-sections by used micro-computed tomography. In our study, the cross-section area of the residual implant was calculated to describe the degradation rate of the $\mathrm{Mg}$ implant. Due to the inhomogeneous corrosion of a magnesium rod in the medullary cavity, the calculated degradation rate based on the images was similar to the real in-vivo degradation rate of magnesium implants.

In-vivo degradation, compare with other metal implants, is an ultimate merit of magnesium alloy. After implantation in the rabbit, $\mathrm{Mg}-4.0 \mathrm{Zn}-0.2 \mathrm{Ca}$ alloy would be reacted with body fluid on the surface and get dissolved in the surrounding body fluid. At first, the released $\mathrm{Mg}^{2+}, \mathrm{Zn}^{2+}$ and $\mathrm{Ca}^{2+}$ could be absorbed by the surrounding tissues and excreted through the gastrointestinal route and the kidney. However, with the increasing time of implantation, more $\mathrm{Mg}^{2+}, \mathrm{Zn}^{2+}$ and $\mathrm{Ca}^{2+}$ ions are dissolved into the solution, the local $\mathrm{pH}$ near the surface of the $\mathrm{Mg}$ implants could be $>10[36]$. As a result, an insoluble magnesium-containing calcium phosphate would be precipitated from the body fluid on the surface of the magnesium implant and tightly attached to the matrix, which retarded degradation. In addition, the corrosion layer on the $\mathrm{Mg}-4.0 \mathrm{Zn}-0.2 \mathrm{Ca}$ alloy contained $\mathrm{Mg}$, $\mathrm{Ca}$ and $\mathrm{P}$, which could promote osteoinductivity and osteoconductivity, predicting good biocompatibility of magnesium. Therefore, it is proposed that the $\mathrm{Mg}^{2+}, \mathrm{Zn}^{2+}$ and $\mathrm{Ca}^{2+}$ released during degradation should be safe. 


\section{Conclusion}

In this paper, we developed ternary $\mathrm{Mg}-\mathrm{Zn}-\mathrm{Ca}$ alloys as biodegradable materials. The following conclusions can be drawn.

The mechanical properties of the as-cast Mg-Zn-Ca alloys can be tailored by the $\mathrm{Zn}$ and $\mathrm{Ca}$ content. The tensile strength can be increased form 105MPa to $225 \mathrm{Mpa}$, and the elongation can be increased from $4.2 \%$ to $17 \%$.

The in-vitro degradation of Mg- Zn- Ca alloys revealed that Zn and Ca not only elevated the corrosion potential of the magnesium alloys, but also influence their corrosion current. A protective layer of $\mathrm{Mg}(\mathrm{OH})_{2}$ and other $\mathrm{Mg} / \mathrm{Ca}$ phosphates was formed on the surface of $\mathrm{Mg}-\mathrm{Zn}$ - Ca alloys when immersed in SBF solution, which declined the degradation rate.

In vitro cytotoxicity assessments indicated that $\mathrm{Mg}-4.0 \mathrm{Zn}-0.2 \mathrm{Ca}$ alloy did not induce toxicity in L-929 cells and are suitable for biomedical applications.

Implanted in rabbits, the alloy did not induce inflammation reactions or affect the new bone formation. We could draw a conclusion that the Mg-4.0Zn-0.2Ca alloy had good biocompatibility.

\section{References}

[1] M.M.Avedesian, H.Baker. editors. ASM Specialty Handbook, Magnesium and Magnesium Alloys, ASM International Materials Park,USA, Ohio, 1999,p. 14.

[2] F. Witte, V. Kaese, H. Haferkamp, E. Switzer, A. Meyer-Lindenberg, C.J. Wirth. Biomaterials 26 (2005) 3557.

[3] P.S. Mark, M.k. Alexis, H. Jerawala, D. George. Biomaterials.27 (2006) 1728.

[4] L.P. Xu, G.N. Yu, E.L. Zhang, F. Pan, K.Yang. J. Biome. Maters. Res .83A(2007)703.

[5] R.Zeng, W. Dietzel, F. Witte,N. Hort, C. Blawert. Adv. Biomate.10 (2008)B3.

[6] X.N. Gu , Y.F. Zheng, Y.Cheng, S.P. Zhong, T.F. Xi. Biomaterials.30 (2009) $484 .$.

[7] Z.J. Li, X.N. Gu, S.Q. Lou, Y.F. Zheng. Biomaterials.29 (2008)1329.

[8] Y.Wan, G. Xiong,H.Luo,F. He,Y. Huang,X. Zhou. Mater. Design 29 (2008)2034.

[9] H.Tapiero, K.D.Tew. Biomed Pharmacother. 57 (2003) 399.

[10] S.X. Zhang, X.N. Zhang, C.L. Zhao, J.N. Li, Y. Song, C.Y. Xie. Acta Biomate.6(2010)626.

[11] P.M. Jardima , G. Solórzano, J.B. Vander Sande. Mater Scie Eng A .381 (2004) 196.

[12] G. Ben-Hamu , D. Eliezer, K.S. Shin. Mater Sci EngA.447 (2007) 35.

[13] H.Tapiero, K.D.Tew. Biomed Pharmacother. 57 (2003) 399.

[14] Y .Ortega, M.A. Monge, R.Pareja. J Alloys Compd. 463 (2008) 62

[15] E. Zhang, D.S.Yin, L.P.Xu, L.Yang, K.Yang. Mater.Sci.Eng.C. 29(2009) 987.

[16] L.P. Xu, G.N. Yu, E. Zhang,F. Pan, K.Yang. J. Biomed. Mater. Res. A. 83A( 2007)703.

[17] H.X.Wang, S.K.Guan, X.Wang, C.X.Ren,L.G.Wang. Acta Biomate.6(2010)1743.

[18] L.Mao,Y.Wang,Y.Wan, F. He, Y.Huang. Heat Treat. Metal. 34(2009)19.

[19] X.N.Gu, Y.F. Zheng, S.P. Zhong, T.F. Xi, J.Q Wang, W.H. Wang. Biomaterials 31 (2010) 1093.

[20] J.Fischer, M.H.Prosenc, M.Wolff, N.Hort, R.Willumeit, F.Feyerabend.Acta Biomate. 6(2010) 1813.

[21] American Society for Testing and Materials. ASTM-G31-72: standard practice for laboratory immersion corrosion testing of metals. In: Annual Book of ASTM Standards. Philadelphia, PA: American Society for Testing and Materials; 2004.

[22] A. Datta, U.V. Waghmare, U. Ramamurty, Acta Mater. 56 (2008) 2531. 
[23] H. Okamoto. J. Phase Equilibria. Diffus.15 (1994) 129.

[24] X.Gao, S.M.Zhu, B.C.Muddle, J.F.Nie, Scripta Mater. 53 (2005) 1326.

[25] J.C. Oh, T. Ohkubo, T. Mukai, K. Hono, Scripta Mater. 53 (2005) 675.

[26] L.Geng, B.P. Zhang, A.B. Li, C.C. Dong, Mater. Lett. 63 (2009) 557.

[27] Y.C. Xin , C.L.Liu , K.F.Huo, G.Y. Tang, X.B.Tian, P.K.Chu. Surf. Coat.Tech. 203 (2009) 2554.

[28] Y. C. Xin, K. F. Huo, T. Hu, G. Y. Tang, P. K. Chu. Acta Biomate. 4 (2008) 2008.

[29] Y. C. Xin, K. F. Huo, T. Hu, G. Y. Tang, P. K. Chu. J. Mater. Res. 24 (2009) 2711.

[30] Y. C. Xin, T. Hu, P. K. Chu. J. Electrochem.Soc.157(2010)C238.

[31] F. Witte, F.Feyerabend, P.Maier, J.Fischer, M. Störmer, C.Blawert, et al. Biomaterials. 28(2007)2163.

[32] ANSI/AAMI. ISO 10993-5: 1999. Biological evaluation of medical devices. Part 5. Tests for cytotoxicity: in vitro methods. Arlington, VA: ANSI/AAMI.

[33] H. SchweikI, G .Schmalz. Eur. J. Oral. Sci.104(1996) 292.

[34] N. Nelson. J Exp Biol 172(1992) 19.

[35] F.Witte, J. Fischer, J.Nellesen, H.A. Crostack, V. Kaese, A. Pisch, F. Beckmann, H. Windhagen. Biomaterials. 27(2006)1013.

[36] A. Simaranov, I. Sokolova, A. Marshakov, Y. Mikhailovskii. Prot. Metal. 27(3) (1991) 329. 


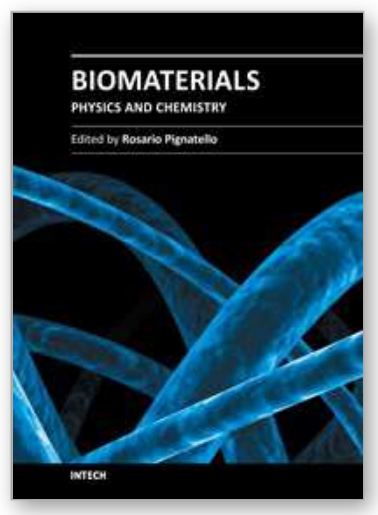

\author{
Biomaterials - Physics and Chemistry \\ Edited by Prof. Rosario Pignatello
}

ISBN 978-953-307-418-4

Hard cover, 490 pages

Publisher InTech

Published online 14, November, 2011

Published in print edition November, 2011

These contribution books collect reviews and original articles from eminent experts working in the interdisciplinary arena of biomaterial development and use. From their direct and recent experience, the readers can achieve a wide vision on the new and ongoing potentialities of different synthetic and engineered biomaterials. Contributions were selected not based on a direct market or clinical interest, but based on results coming from very fundamental studies. This too will allow to gain a more general view of what and how the various biomaterials can do and work for, along with the methodologies necessary to design, develop and characterize them, without the restrictions necessarily imposed by industrial or profit concerns. The chapters have been arranged to give readers an organized view of this research area. In particular, this book contains 25 chapters related to recent researches on new and known materials, with a particular attention to their physical, mechanical and chemical characterization, along with biocompatibility and hystopathological studies. Readers will be guided inside the range of disciplines and design methodologies used to develope biomaterials possessing the physical and biological properties needed for specific medical and clinical applications.

\title{
How to reference
}

In order to correctly reference this scholarly work, feel free to copy and paste the following:

\section{B.P. Zhang, Y. Wang and L. Geng (2011). Research on Mg-Zn-Ca Alloy as Degradable Biomaterial,} Biomaterials - Physics and Chemistry, Prof. Rosario Pignatello (Ed.), ISBN: 978-953-307-418-4, InTech, Available from: http://www.intechopen.com/books/biomaterials-physics-and-chemistry/research-on-mg-zn-caalloy-as-degradable-biomaterial

\section{INTECH}

open science | open minds

\section{InTech Europe}

University Campus STeP Ri

Slavka Krautzeka 83/A

51000 Rijeka, Croatia

Phone: +385 (51) 770447

Fax: +385 (51) 686166

www.intechopen.com

\section{InTech China}

Unit 405, Office Block, Hotel Equatorial Shanghai

No.65, Yan An Road (West), Shanghai, 200040, China 中国上海市延安西路65号上海国际贵都大饭店办公楼 405 单元

Phone: +86-21-62489820

Fax: $+86-21-62489821$ 
(C) 2011 The Author(s). Licensee IntechOpen. This is an open access article distributed under the terms of the Creative Commons Attribution 3.0 License, which permits unrestricted use, distribution, and reproduction in any medium, provided the original work is properly cited. 